$\xi=-1$

\title{
Dimensions of the Javanese culture and the role of Parents in instilling values in creative industry entrepreneurship
}

\author{
Agus Hermawan $^{1 *}$, Mohammad Arief ${ }^{2}$, Wening Patmi Rahayu ${ }^{3 *}$ \\ ${ }^{1,2,3}$ Senior lecturer at Economics Faculty, Universitas Negeri Malang \\ *Corresponding author E-mail: agus.hermawan.fe@um.ac.id
}

\begin{abstract}
This paper reveals how the sources of Javanese culture, which has been instilled by parents of children as the new generation of the successor to the family business, can act as values of sources of inspiration which shapes the behavior of entrepreneurship in the creative industry. Entrepreneurship in family businesses uses these Javanese values as the standards of the family's belief, which makes the principles as an identity that guides them in entrepreneurship and creates a way of life in the running entrepreneurialism. The method used in this research is a social constructionist, narrative and interpretive. The narrative-based research approach is done through data collection with depth interview, and non-participatory observation as well as analysis of the theme that create the methodological foundation. The ideas emerged and developed from in narrative face-to-face that became a proposition of research findings. Findings clearly indicate the relationship between Javanese cultures which is owned by parents has been the values that are believed by the second generation and this has motivated their behavior entrepreneurship, and impact the learning element of entrepreneurship, as well as orientation in entrepreneurship. The internalization of the values of Javanese culture Bapakisme (paternalism) and Rukun (harmony) have motivated the behavior of entrepreneurship when running a business relationship. Javanese cultural values implemented in the form of obedience to parents, keeping harmony, learning competitors, watching of God, sincere, assertive, fortune flows, trust, motivating, cultivation of religious values, and independent values. The research provides new insights into the culture of entrepreneurship at the local level and links the insights to the cultivation of cultural values in entrepreneurship, which is realized in everyday behavior. The construct built provides the possibility of new learning materials for the perpetrators of entrepreneurs in Indonesia, where $47 \%$ of the population of Indonesia is Javanese ethnicity.
\end{abstract}

Keywords: Javanese culture; cultural and entrepreneurial values; entrepreneurial learning; family business

\section{Introduction}

The field of study of this research is family business management where business owners are engaged in an intense communication with the family and social environment in the form of the planting of Javanese cultural values in business. The transformation of Javanese cultural values is a form of informal entrepreneurial education given by parents for the next generation of children. The strong dominance of parents in Javanese culture is a concept that characterizes the business culture of the Javanese people (1). Family business owner is always emotionally involved in instilling the business culture to the next generation. (2) indicate that only $30 \%$ of family businesses are successful until the second generation and $10 \%$ until the third generation. $(3,4))$ prove the influence of national culture on entrepreneurial characteristics. The research approach by (5) also focuses on the evidence that national culture has an impact on aggregate entrepreneurial behavior. On the cultural linkages and entrepreneurship, entrepreneurship is a major driver in developing the economy although a developing economy's culture may be an inhibitor (6). The history of research that analyses the relationship between cultures with different concepts, in addition to entrepreneurship in different countries and crosscountry comparisons have been conducted $(4,7)$. Research on Javanese cultural transformation in the family business focusing on the next generation is very noteworthy to be analyzed. The philosophy of Javanese culture that is full of moral values are taught between generations heritage value and is a mystery whether they are the ideal inspiration for the next generation of family business owners or not. It plays an important role in shaping the way people see the world, influences the direction to moral conduct, as well as impacts the behavior in maintaining social order and business (7). Entrepreneurial learning will happen intentionally or unintentionally, where people are naturally inclined to imitate, explore, take and internalize the social role, knowledge, skill and practice that end up in the planting of the cultural values in it. This study goes further to delineate a number of specific differences in Javanese culture values in business. Using Java's characteristics of paternalism and harmonious culture, this research tries to describe the relationship between cultural values instilled by parents with the perception of the behavior of the second generation of the family business when Javanese culture is applied in the relationship with parents, competitors, employees and the Lord. The transformation of cultural values in entrepreneurship is not being separated from the role of parents and the environment as the role model for the children.

The family company examined is creative industries based, located in a small district East Java, Magetan, the border of Central Java. The residents are still using the Java language as the primary communication tool. There are several other reasons that determine the research subject. First, the 3 research subjects are young (30-40 years), who continued the effort their parents, where they 
are now the main actors involved in as a full-time manager that manages the activity every day. This creates a strong business culture where consequently suits the purpose of research. Second, the research subjects are chairmen of the association of creative industries of leather tanning, footwear and coffee product where their leaderships are recognized by their neighborhood business association. This circumstance is able in revealing the complexity of the implementation of the Javanese business culture in communicating with the government, competitors, business partners and social environment. Third, the company is growing and developing its sales turnover up to 70-120 millions Rupiah per month. Fourth, the entrepreneurs are open in conveying their thoughts regarding the business values of Javanese culture accepted from the parents, social environment and personal experience.

\section{Literature Review}

\subsection{Javanese Culture}

Javanese Ethnic dominates $42 \%$ of the population (205 million) of the 300 ethnic groups, and they always possess leading positions in Indonesia BPS, 2010). Java ethnic is the largest ethnic group in Indonesia that originated from East Java, Central Java, and Yogyakarta. The majority of the Javanese people embraced Islam, which is around $95 \%$. The Javanese divided into three "streams": santri, abangan and priyayi. According to (8), the Santri followed an Islam orthodox interpretation, the abangan was the followed a syncretic form of Islam that mixed Hindu and animist elements (often termed Kejawen), and the priyayi was the nobility. While (9) simply divide the class into the priyayi or the noble ones, and the wong cilik or lower ones. The structure of the society provides a high place for the priyayi, which belongs to the governmen employees, teachers, and clergies. However, the lower class consists of farmers and traders, unless they are religious leaders. Javanese Islam, just like Indonesian Islam, generally is a moderate Islam, and they tend to apply tolerance towards other religions in their religious practice (10). The measure of the success of a Javanese is when one's life is balanced between material needs, spiritual necessities, and emotional desires. Javanese life has a tendency to maximize the harmonization in oneself, which is in relation with the relationship with others nature and God. Javanese pluralism that is in contact with Islamic culture has caused the Javanese culture to be rich in meaning. The combination of Islamic and Javanese culture has made a new harmonized arrangemen (11). Religion for the Javanese religious groups or the strong Islamic upholders is a guide and a way of life to socialize and do business.

The Javanese business ethics refer to two fundamental principles, the first principle is the principle of respect for the elderly, and the second is harmony principle (12). Everyone Java is required to be able to live in harmony and to maintain harmony with each other. Similarly, this is also in accordance with the position of respect in community and family (13). The first principle of the Javanese community is basically arranged in a hierarchical manner, where everyone has a position in accordance with the grade. Everyone has a responsibility to position itself with the appropriate position When they talk and they behave, the Javanese have to adjust to the degree and position of the other. The principle of respect regarding all relationships in society is hierarchically organized. Everyone is familiar with the place and duties. Those who have a higher position must be respected, while the higher position must have a fatherly nature or bapakism or motherhood nature for the lower position. Bapakism is a form of paternalistic relationship between leaders and followers (14). Bapakism is a term that means an ideal father who is highly respected, which has the charisma and the duty to take care of the surrounding community member. The social norms of Javanese are an extension from the family norms. A father has the character of a teacher or a scholar who deserves to be obeyed and imitated, or digugu lan ditiru, by his followers. The Javanese respects and trusts their superiors like they do to their own fathers (9). In case someone does not agree with anoth- er's opinion, disagreements are done in a subtle way. Javanese culture emphasizes the importance of imitating and learning from a scholar who had virtue in life. On the other hand, a father must nguwongake or civilizes family members or followers by displaying characteristics such as virtue, wisdom, and, protection to the family interests. (12). In creating harmony, people especially have to bring it through the group is not individualistic (9). This value is important in all aspects of the organization of Java and embodied in the collective decision-making process, consensus and cooperativeness (gotong royong). Mutual help and share the burden, in the family and society, the concept of social and family harmonize achievement. A reflection of the behavior that appears is unselfishness and respect for collective decisions and groups. Open conflict considered as incompatible principles and will appear only in an atmosphere of extreme. Thus, if a leader openly expresses their feelings by using harsh words, this means that the error is almost unbearable subordinates and subordinates should be aware of this (12). Committed to the principles of harmony and respect principles, will lead to a harmony in social life.

\subsection{Values, Culture and Entrepreneurship}

There are different definitions in the literature concerning values. (15) defined value as a deep tendency when someone sets specific actions when dealing with others. (16) argues that value is the desired conditions, purpose, object, or behavior in certain circumstances and applied as a normative standard for assessing and choosing among alternative behaviors. Value is intrinsically common but permanent and may cause measurable actions. The assumption is that one's value can basically be submitted by groups or individuals who later became social values.

Culture can be seen as the external influence for others, such as making the individual motivated or inspired and economic demands in the implementation of the entrepreneurial function, for example wanting to be recognized and reading a chance. Driving factors from the government, for example, has a greater influence entrepreneurial success (17). (18) revealed that culture affects people's ability to understand the opportunities and to respond to the entrepreneurship acts, where each has a very different possible response in behavior even with the same environmental conditions. The effect of an entrepreneurial culture is not limited to directing and influencing individuals. Culture is made up of the environment, family, and community agencies that have an impact on the whole individual, if the pattern transformed is perceived as the same value.

In-depth researches in the social sciences have shown a link between a values set, behaviors, beliefs and (19). Some of the findings stated that cultural differences, where the values and beliefs of individuals embedded, will affect a variety of behavior that includes the decision, motivation (20), and to become entrepreneurs (21) and (22) declare that organizational culture will affect the company's conduct in entrepreneurial activities. (23) found that family firms will be successful if it can take advantage of a more formal culture and professional that focuses on the individual, accompanied by understanding the nature of family and fostering personal relationships among family members. Family enterprise culture evolves over time, which describes the dynamic relationship between variables such as values, history, and achievements of the organization owners, industry competition conditions, and national culture. Research shows that the corporate culture of a family company is more positive if it is accompanied by the cultivation of values to the new generations, where it especially will look better the strategy implementation. History and collective identity on the members of the family will provide the tested core values and the standards of behavior that can lead to the success of the transformation culture from top to bottom (24).

\subsection{Family Business and Entrepreneurial Learning in Javanese Culture}


Relevant dimensions to determine the nature of a family of companies includes the degree of ownership, family business management model, and the ability to transfer the culture from one generation to the next. In this study, a family business is defined as an enterprise in which parents or peers have domination in managing control and transforming cultural values to the next generation to serve as general guidelines to achieve organizational goals (25).

Javanese leadership culture is very strong whereas father is a central figure. Leadership is a process of influencing others to understand and agree on what needs to be done and how to do it, accompanied by the process of meaningful attempts to keep the individual and organization members collectively influenced in achieving a common goal (26). Leadership is important to influence organizational effectiveness. The presence of a leader in the family organization from generation to generation describes the historical trajectory that will move forward through the implementation of cultural values across the history, which is adopted in accordance with the change of time. (27) affirms that entrepreneurial thinking for leaders about what to do and how to do it will create the culture formation and change. Leadership is the deciding factor for a culture of environmental society that has expectations regarding the leadership role in shaping the character associated with efforts that should be done in the community (28). (29) stated that culture is a unifying force in organization, that there is no culture which is not homogeneous and universal, and that each culture will bring the each cultural values. (30) explains that, from early childhood, a leader is very dominant in influencing the cultural mythology that they have.

Every entrepreneurial behavior is undoubtedly based on social and cultural backgrounds. (31) assert that the entrepreneurial process occurs when interaction between individuals, their intuition, society, and culture occurs. The dominants of the head of the family will play a collective role that affects other family members and provides entrepreneurial spirit as desired. It is believed that the source of transformation and entrepreneurial spirit lies within the individual is from the family members (32), and that will lead to the planting of an entrepreneurial culture in the family. (33) showed entrepreneurship based on "a strong hierarchy of values" (p. 258). (34) has identified that the individual behavior is partly determined by their cultural upbringing in the family and society. Individuals have the basic ability to deviate from cultural norms and react in a way that is creative, innovative, damaged or unexpected, that is, in ways that would be considered contrary to the social norms and customs. Intuitively, entrepreneurial world is formed and interpreted differently. In each individual, the attitudes, attributes, behaviors, and values are created at the interpersonal level (35). The culture is created by the interactions and determining their future interactions. The future of the present generations is determined by the previous generation. Interaction leads to the exchange of knowledge, experience, and recognition of status, which in turn led to the strengthening of identity. Individuals, at some level, choose a number of different cultures, experience, and cross-generational knowledge, and they certainly will behave in different ways according to the search for identity that they want to be. Continuous social interaction within the family allows shaping, interpretation, and values internalization associated with the overall economic activity and behavior of entrepreneurship cultural values.

Attitudes and intentions of individuals related to entrepreneurship and are therefore influenced by the prevailing culture around them. It also includes the values of life, shared attitudes, and motivations which affect a particular individual entrepreneurship motivation (36). Culture is a negotiated product and shared meanings; it emerged from the social interaction of members of the family. (37) reveal that stable and successful companies usually learn the first-hand experience. Children will learn from their parents as the people nearest. It emerged in the grown business sector that constantly encourages the exchange of information and knowledge among family members. Company in which parents become a figure, wherein the culture of Javanese is considered as the father, business owners and part of their core family collectively allows each one to play a part which is important for each one to perform a transformation of culture as a legitimation form of practical management control. In this case, the culture control based on the norms of the family together is the most dominant that in the end simplify the process and control of result (1). Companies that are controlled by a generation of young families makes it possible to adopt a "clan culture" that focuses on short-term orientation and establishes a "culture of hierarchy", to uphold and focus on maintaining the stability of the family business (38).

(39) reveals the business values in Javanese culture, where the research prove that the Javanese culture wise possesses many values that are relevant to the business world. Those are the principles of determination, hard working, thoughtfulness, smartness, accuracy, judge of fullness, creativity, being cautious, and spindrift, controlling lust and passion, pursuing new information and knowledge, fair in doing the transaction, building a good relationship with the stakeholders, and having a high social responsibility. Local culture can be found in the Javanese community's sayings, advice, slogans, the chronicle of the Java ancient land books, and messages inherited in everyday life. The local culture better describes the specific phenomena that will be the characteristic of a specific community, in this case the people of Java, for example alon-alon asal klakon or one slowly moves as long as they eventually reach the purpose, rawe-rawe rantas malang-malang putung or one should work hard and not give up, ikhlas kiaine manfaat ilmune or a sincere leader's knowledge will be beneficial, patuh marang guru barokah uripe or being obedient to the teacher will make one's life prosperous. (40) stated that in character education through songs, Javanese transformed moral values and culture to be a form of moral education or the education on the goodness of life. (41) reveals the ethical values of Java that supports the business world that is still relevant as a form of embroidery philosophy: tatag tanggon trengginas or opinionated, trustworthy, competent; sepi ing pamrih, rame ing gawe or do not expect anything in return and work hard instead; ora kuminter lan nrimo or do not feel clever and hopeless; tuna satak bathi sanak or one loses money, but gotten a brother.

\section{Research Methodology}

\subsection{Method}

A qualitative method is different than a quantitative approach. Qualitative method provides the necessary data to explore complexity. Qualitative research seeks to interpret the social phenomenon by producing a rich understanding of the meaning and structure of the complex social actors who establish patterns of kinship in their social environment (42).

This study is an exploratory and descriptive investigation that selects three businessmen informant of creative shoe industry, leather, and coffee that offers the products of local people. The commercial activities of the company's business are based on the nature by making use of leather and coffee. Three methods of data collection were used: interviews, observation, and literature analysis. To capture a cultural phenomenon, researchers are working to build relationships with informants. The close relationship allows researchers to gain access and openness of all study subjects. To handle cultural sensitivities, researchers built close, personal relationships with the subjects. The relationships grow gradually as our friendships and mutual trusts became stronger. The view on the reality of the organization are negotiated and constructed by the collective consciousness of the subject participants. Therefore, researchers are working to understand the transformation of cultural values is implemented in the company. To capture a detailed understanding of how to conduct the culture built and established, the framework of the principles and concepts of Java cultural values of paternalism and harmony are adopted (43). The frameworks used to assess the cultural values are implemented in the business associated with leadership, competitors, and the relationship with the employee and God. Javanese culture is used to test the cultural 
values of the generation perspective which currently controls the company.

\section{Data Analysis}

The analytical strategies used are a combination of narrative approaches and thematic analysis (44). The analysis is conducted in several steps through reading and re-reading interview protocols, with rather differing perspectives linked to the various phases of analysis. Preliminary analysis is accomplished during data collection and continued during the transcription of the recorded interviews as the author become familiar with the material. Themes emerge from the data and the literature review. These themes are strongly associated with entrepreneurial behavior. Interpretation is continued with a close texts examination of transcripts and what linguists identify as "idea units, stanzas, strophes" (45).

\section{Results and findings}

Business leadership in the Java is essentially attached to the culture of the people. A leader-owner of a business is a manager who runs the organization's culture. The business culture is obtained from ethical absorbed and reinterpreted from the cultural roots of parents and community. Based on the cultural roots of paternalism and harmony as the basis of Javanese culture, business practices of Javanese culture revealed four themes that indicate the relationship based on empirical conditions.

\subsection{Javanese Cultural Dimension: Parent and Child Relationship}

Bapakism as a form of paternalistic Javanese culture is an important cultural value that is seen in Javanese business conduct Position the father of the child is a role model that provides cultural values in the existing businesses. Father is a figure who is an example of running a business. In the teaching business, there is the indication that a father's silence is even followed and adhered to the child as the child's behavior. The process of respect for parents is shown by subject1 (Bas) with his statement:

"My parents are not the type of people who likes to talk like teachers, who likes to advise. Nonetheless, in instilling the values of life, my parents put more emphasis on deeds and actions by giving examples of behavior. My parents are hardworking and always think positive, and taught me to work hard and I respect them."

Subject2 (Eko), looked at the relationship with his parents by the experience of tidal dynamics that are not always harmonious in terms of the family management business. Cultural values that will be invested did not always run smoothly. There is a side of a conflict that must be faced when having to run the family business.

"I was actually in the same cadre with my father, but there was frequent disagreement with him. I did not like the system when it was about to be addressed, the clashes continued. Then I said, "I relented,". In the end, my father died, I decided to return and continue the family business by laying off some worker for the company to run better. Before I make a decision, I always ask for the permission and prayer from my mother."

Parents and child relationship in the dynamics of subject3 (31) looked at the relationship between the need to maintain harmony, with the belief that the father does not always dictate the child to continue the family business. Coercion is often regarded as not considering harmony in relationships and family ties.

"If the business endeavors, it can last until the third-second generation and so on. Father instills unity as the capital, and teaching this is harder than forcing the children to continue the business. What is applied is giving 'guidance' for the children. The important thing is to direct. Rather than looking for a job, is not better to make the job. Rather than getting monthly salary, is it not better to give salary. In the role of parents today, what is important is prayer. We are working today not only look for the profit, but we look for peace in the workplace".

\subsection{Javanese Cultural Dimension: Relationship with Employees}

In Javanese culture, the owner and employee relationship is an important relationship to the productivity of the company. Cultural relations are built as the concept of paternalism that requires both trust and understanding of the employees towards a more efficient manager (46). A relationship that is based on the principle of patron and client relationship between the two different roles in which an individual with socio-economic status of the higher use of influence and resources provides protection and benefits for a person whose status is considerably lower. The basic objective of the actual patron-client relationship is to provide basic social for subsistence and security. Employees are considered more as part of the family members that every basic need must be fulfilled, even when they do not become employees anymore, they are still deemed to be family members.

"Generally, I work with young people. If they get married I told them to resign, but it does not mean they are fired. I tell them to work with their own capital but take order from me and the marketing is my part if it meets any difficulty. I let them do things independently. That is also what is instilled by my parents." (subject2)

The honesty value being the point that subject 1 relates in the company's internal management. Honesty means willing and able to say things as they are. When doing business, good stuff needs to be said good and the damaged goods must be said damaged. Honesty can be likened to "Amanah". Amanah is when one is given the trust; he or she does not cheat. What one says is always right and when one promises, he or she does not break it.

"I always invite my employees to pray on each break. From the beginning, I do not tolerate theft by employees in the leather business. After I warn them and they do not stop, then I fired the employees with disrespect because they are not honest. Planting religious values of honesty and helping others is emphasized by my parents. Indeed, in a business like this, there are even times that we get no profit at all. The important things are when the customers do not run and the employees can live and not lay off employees."

In Javanese culture, a conflict is considered as incompatible values and will only appear in the extreme situation that does not make both parties comfortable. The pattern of this relationship occurs also in employee's relationship if a leader openly expresses their feelings by using words that are harsh and abrasive, this means that the mistake is fatal and employee should be aware. Before that happens, subtle ways are usually used.

"Generating marketing is not by being hard on employees but by speaking from the heart. When talking with the heart, the employees will be even motivated, and they will work without my asking. No need to check. I only need to check the marketing. I do it a few times. If employees do not come in, I check them. If there are events that are not good, it means that it is not good. Then the employees feel appreciated, so the one who watches them, God". (Subject3)

\subsection{Javanese Culture Dimension: Relationships with Competitors}

In the modern business, business networking capabilities are more meaningful than simply the pursuit of profit. Javanese culture views that the more business partners got; the more companion's one has (dulur). They have the courage to sacrifice the condition of having no profit at first, by hoping to profit in the future with efforts to win the business partners confidence. Javanese culture business is not just to make a profit, but business also includes noble values common welfare (47). The principle of life is that the Java people living in harmony and respect, with the goal of com- 
mon prosperity alive. The construct of a traditional Javanese is how abundant harvest can be for families and communities in need. The concept of business relations for subject 1 is the value instilled by parents that are more concerned with submission to God, and the principle that everyone basically has their own portion of profit from God. There is a tranquility attitude in avoiding conflict for the sake of harmony.

"If the father had business dealings (debts) with others' business, he did not react with emotion but with efforts and resignation to God. Parents instill us with value belief that "when it is our sustenance, like chickens' dirt will be money. However, if is not our fortune, even if we had it in hand it can still escape, may God give out fortune through other ways. Besides the positive thinking, there is also sometimes negative thinking. If it is too loose with other people, it is not necessarily good. We need to look at the situation. To those who really cannot afford to pay the debt, yes we let the money go. Nonetheless, to those whose lives in pleasure, we still have to charge."

In the modern business theory, the competitor is the one who should be overpowered and seized in the market share. In Javanese business culture, they are not regarded as competitors which must be defeated, but to provide the best products for consumers to create a good product without considering them as competitors. Subject2 stated this:

"Karya Pahala (a competitor) has 8 stores, I have one store. We do not refer to them as a competitor. If competitors come for us, let us produce together and see the products. That's who we think are competitors."

This view of the competitor is regarded as an alliance to subject3. Javanese culture has a philosophy of trengginas or deft as the pillar and the principle of this coffee entrepreneur, as his statement:

"The competition usually happens between employees, and the business owners are good to each other. When coffee prices rise, the price of everything also rises. If I compete with big factories, I'm glad. If I lose I do not waste anything, it is called learning, but they are a big factory. What matters to me is how to find out how they are successful. I will learn to continue to know their secret. It should be like that, I must learn. There is a large company, we have to learn. Do not ever stop learning."

\subsection{Javanese Cultural Dimension: Relationship with God}

Javanese cultural dimensions of business relationship with faith are still a major grip in behavior. The relationship between religious values and corporate culture has become more robust, supported by many research results $(48,49)$. $(48)$ show how entrepreneurship is run internally and through various contexts based on the religion in which the values of religious beliefs are intertwined with cultural values and both affect each other in managing entrepreneurial behavior. Thus, the search for religious cultural values related to the behavior of the Java business becomes easier to understand theoretically and practically.

In religious behavior, subject 2 is providing praying space for employees is a realization that every employee has the right and obligation to balance its work relationship with God relationship. The working relationship is with peace of mind. Likewise, with subject3, he is providing better means of building, has made a small mosque (langgar) which is a part of his main building house, as a form of egalitarian relationships with employees. Religious values as a product of God are considered key to finding peace and success in business, as well as a place to complain the problems facing the business.

"I'm not too concerned about the fortune, it just flows. Never suspected. Sometimes in the heat of mind, I ask, why was it not sold? We continue to insist to the customer, it failed. At break time, we pray, if there is a time at 8 , we pray Duha, If is at night I ask God's help in tahajjud. "(subyek3)

Subject1 is basing himself on religious principles of Islam that were followed consistently by bringing employees together to the mosque to worship and by not using banking services to expand its business. Parental advice and the values of Islam which prohibit interest became the foundation for his cultural value.

"What I own up is my own capital. I had never used the bank's capital. My parents had used the bank's capital; from there they advised me to use my own capital. Since interest is usury, which turned out to be the impact for the future and it is not from the time we receive the money. There are many cases, although there are also successful companies because they are borrowing to the Bank. I see a lot of my friends in difficulty because they are billed by Bank."

As a summary of descriptions of deep interviews, values of an entrepreneurial management culture in Java is still associated with the modern and the traditional cultural values of Java. This study articulates entrepreneurial learning aspects as an individual in the very dimension of internal family and social at the same time, also when employers have to deal with competitors.

\subsection{Entrepreneurial Learning in Javanese Family Business}

Bapakism as a form of paternalistic Javanese culture is an important cultural value that is seen in the Javanese business conduct. Father is a figure who is an example of running a business. Respect is a behavior required to anyone higher up in the social status, and all the relationships in the community are organized hierarchically, which also reflects the order of the society. Everyone has a place and a special task in society and contribution to creating harmony. People in higher positions must be respected and never express his opposition (9). Those in the lower position should be treated with kindness and a sense of responsibility for their welfare. Ideally, a leader is responsible for the safety, prosperity, and dignity of his followers, like patron-client relationships.

The principle of harmony is to avoid an open conflict. Javanese want to attain this ideal in every relationship, in small town, and in every group and organization. To act in harmony means to press all personal tensions and prioritize harmonious in social relationship. The ability to suppress negative feelings and tension due to the conflict will create a harmonious. In practice, the pillars are sometimes ignoring personal interests for the sake of the group. Individuals should always act together with the position of the group. Javanese understand the ethics and values in harmony since childhood and this lasted continuously from generation to the next. The family is the main source of the transformation of the warmth value, comfort, and security (50). Attempts at reconciliation are based on consensus. Ideally, deliberation is a procedure in which all voices and opinions heard. They are all considered to be correct and theoretically, they contribute to the solution. Joint deliberation is believed to provide a guarantee for the right decision if it does not find a solution. It reflects the deliberations totality that should be kept that always end in consensus. Therefore, it is necessary for all parties to release their personal interests.

Table 1: Informal Learning in Javanese Business Culture

\begin{tabular}{|c|c|c|c|}
\hline \multicolumn{4}{|c|}{ Bapakisme and Rukun as a Basic Views of Javanese Culture } \\
\hline $\begin{array}{l}\text { Parent and } \\
\text { Children } \\
\text { Relationship }\end{array}$ & $\begin{array}{l}\text { Employee's } \\
\text { Relationship }\end{array}$ & $\begin{array}{l}\text { Competitors } \\
\text { Relationship }\end{array}$ & $\begin{array}{l}\text { Allah (God) } \\
\text { Relationship }\end{array}$ \\
\hline 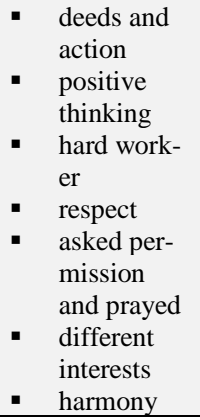 & $\begin{array}{ll}\text { - } & \text { self- } \\
& \text { reliance } \\
\text { - } & \text { independ- } \\
\text { ent } & \text { encourag- } \\
\text { ing for self } \\
\text { developme } \\
\text { nt } \\
\text { trust } \\
\text { - } & \text { honesty } \\
\text { cultivation } \\
\text { of religious } \\
\text { values }\end{array}$ & $\begin{array}{l}\text { not emo- } \\
\text { tional } \\
\text { - } \text { attempted } \\
\text { happy sur- } \\
\text { render } \\
\text { - believe in } \\
\text { God } \\
\text { - positive and } \\
\text { negative } \\
\text { thinking } \\
\text { compete } \\
\text { with the } \\
\text { quality of } \\
\end{array}$ & $\begin{array}{ll}\text { fortune } \\
\text { flows } \\
\text { ask } \\
\text { God's } \\
\text { help } \\
\text { do not } \\
\text { trust } \\
\text { banks } \\
\text { forbid- } \\
\text { den usu- } \\
\text { ry } \\
\text { the wor- } \\
\text { ship to- }\end{array}$ \\
\hline
\end{tabular}




\begin{tabular}{|c|c|c|c|}
\hline $\begin{array}{ll}\text { - } & \text { directing } \\
\text { independ- } \\
\text { ent }\end{array}$ & $\begin{array}{ll}\text { - } & \text { part of the } \\
\text { family } \\
\text { - } \\
\text { speak from } \\
\text { the heart } \\
\text { - } \text { motivate } \\
\text { - } \text { rewarding } \\
\text { - } \text { God is } \\
\text { watching }\end{array}$ & $\begin{array}{l}\text { the prod- } \\
\text { uct } \\
\text { - learning } \\
\text { from com- } \\
\text { petitors } \\
\text { - no competi- } \\
\text { tors } \\
\text { - endeavor } \\
\text { - } \text { sincere } \\
\text { - } \text { assertive }\end{array}$ & $\begin{array}{l}\text { gether } \\
(\mathrm{Ja}- \\
\text { maah })\end{array}$ \\
\hline
\end{tabular}

\section{Source: Transcripts Data, 2016}

In a typology of entrepreneurship, business type of "Craftsman" is an individual who follows a trail and steps entrepreneurship behavior of role models in the family members who serve as an example. While entrepreneurs "like father like son", is associated with the model "craftsman", namely businessmen and entrepreneurs entering the business policy by making the father/mother as a role model (51). (52) stated that the models are presumably in line with the values of Javanese culture where most entrepreneurs who run their business because the displacement generation will tend to mimic and adopt the values of his parents. This typology provides an indication of sociological factors of family relationships that encourage individuals to become an entrepreneur. Although not all family company are successful, the literature suggests that success of the family company is usually because it has a competitive advantage and is related to the family culture that was created. Family company literature asserts that family corporate culture has a strong effect on the goals achievement (53), and the family business strategy (54).

The findings offer interesting insights regarding the business culture of Javanese families on a local area. The research is seen in four types of relationships associated culture: parent, employees, competitors and Allah (God) relationships. Relationships with parents are directing children to absorb the cultural values of deeds and action, positive thinking, hardworking, respect, ask permission and prayed, different interests, harmony, direction and independent. Javanese family life intrinsically inspires each difficulty and challenges. A strong orientation towards family is expressed from the collectivism attitude is strong (5). This study indicates that the strong hierarchical structure has encouraged children to respect the position of status and power owned by the parents. Plea to parents will perform actions that reflect adherence expressions of respect despite differences of opinion conflict in the family, and the child remains in a position to obey. Succumbing means efforts to seek and achieve harmony in the family. (5), noted that Indonesians tend not promote self-interests, individual competitiveness, and to help each other (gotong-royong) and collective achievement. In fact, any business competitor's research shows not to be perceived as "the enemy", but rather a source of business inspiration and an invitation to the direction of a positive competition. The positive conjecture nature against anyone is a form of pre-action that is in line with efforts to form a harmony to minimize conflicts. There are two values that are important factors that drive the behavior of the family business: family purpose and values (55). Family purpose generally includes maintenance and support between family members. It trends more to the effort than direct but still gives freedom for children to make decisions, where parents want to be respected as role model. Consequently, those family relationships in Javanese culture remain their efforts to achieve harmonization relationship in business. There are indications to stay on top of hard work. Hard work is the most commonly reported entrepreneurial characteristic in the literature. Hard work underpins the dedication to work long hours to achieve organizational goals (56). Real work determination and ability to work hard is a critical success factor in an entrepreneurial endeavor (57). Parents Expectations within Javanese culture led to freedom and self-reliance growth.

Relations with workers indicate that there are efforts to motivate employees to be independent (self-reliance) by giving businesses freedom if they are married. The condition pushes Javanese employers to encourage each individual employee to be able to develop themselves, but still with employer supervision. Javanese culture is emphasizing to employees in the form of trust and hon- esty as a meaningful cultural values called tanggon and trengginas. Tanggon means trustworthy and dependable, followed by a firm stance when one violates the rules because one must be accompanied by an honest attitude. Trust and honesty in one's behavior are backed by the religious values cultivation, by providing facilities for praying at the office, and the employees are accompanied for the prayer in mosque together. Employee relationships with employer tend towards patron and client, father and son because employees are considered family part. This is evident from the fact that subjects make efforts to constantly strive to speak from the heart in motivating employee with a reward if it is accompanied by achievement. They reward their accomplishments as a meaningful demand management targets in Javanese family, which also means that there is an attempt to train more skilled and competent employees which meaning is trengginas in Javanese value. Thus the spiritual values of Islam appear to significantly enter the working world. In Islam, there is the main belief that God watches. Tangible expression of the results of this study appears in the subject's actions that do not always continue to supervise employees, because trust and honesty, with the confidence that their work will be supervised by God. (58) found that family business that promotes close relationships will inspire employee loyalty to be strong, and it will result in a greater performance (59). While the family business is giving more confidence to the employees of a business family members that are more committed $(58,60,61)$ and work harder (62). In Javanese culture has the value of tatag, which is depicting pertinacious in stance or consistent to act cautiously, to the challenge without any sense of doubt and ojo kuminter who showed humility of Javanese to want to continue to learn, and still feel less intelligent (39).

In Javanese culture, associated relationship with competitors, a strong pillar principle adopted is that competitors are never considered to be "opposed" or to be defeated. Competitors are 'friends' that can be used as a source of inspiration for the better by learning from competitor and "sparring partner", namely to produce the race to create a superior quality and not meaningful defeat and discredit. (63) looked at in cognition-culture of a Javanese; found that the expression of rukun agawe santoso, congkrah agawe bubrah or harmonious make prosperity, conflict makes disparity, which encourages the emergence of peace and harmony and to make the world full of safety by avoiding conflict. Meaning that morality raises harmony and avoid conflict. The meaning is also supported by the expression of tuna sanak bathi sanak or loss the money, but fortunate the fraternity. Ethics of Javanese culture is not just making a profit, but the profit achieved after trust (39). Business is also committed to welfare together. The basic principles of Javanese are living in harmony and respect to realize common prosperity. The concept of it is the construct of traditional Javanese that still exists in modern times. The sincerity of the attitude of Javanese culture accompanied with assertiveness in business is seen from the efforts which continue to maintain harmonization and association with the competitors. They sacrifice themselves for not being emotional in attitude and characterize the existing act. Indonesian society does not want to put forward a motive ego, self-promotion, and competitiveness of the individual; but mutual help (gotong-royong) and the success of the collective accomplishments are important (64). (13) reveals the concept deserted sepi ing pamreh, rame ing gawe, meaning that do without expecting a reply and work diligently. This attitude is called for not just looking for personal gain at the product quality expense, but work diligently and sincerely to get satisfactory results for the sake of the common good to cling to God, as a guide to life, because the fortune is set up.

The religious dimension influence of the business remains in the attention of researchers, where religious values have a place that influences business behavior (65). Relationship with Allah is seen as a crucial and important dimension in business, there is a condition in which the values of Islam have strongly influenced the actions and behavior in business, and strive to be embedded in everyday business conduct. Efforts to close business relationships and religion is intimately related to the efforts led to provide a 
place of worship, made a 'complaint prayer', if the business issues happen, and invite togetherness and equality by praying together, with the principle that human beings need God in doing their business. Implications and implementation are very clear to avoid borrowing from banks because interest is usury and forbidden. Interest to business life is motivated and determined with the principle that life is by God, luck must be cultivated and profit depends on God. This submission is in line with the cultural values of accepting, which teaches people to accept what is already defined and outlined by God (39). Surrender is prohibited, and the Javanese will strive to maintain self-esteem and family and job. Accepting in total shows the value of trust, worked hard to finally submitted the results to God. The existence of the Java community is classified as santri (43) that indicate the strength of culture to implement business basing on religious values as a part of life and business conduct. Religious orientations are evident factors that support a belief that religious values are social capital that forms members to tackle entrepreneurship challenges (66). Religious faith appears to have become a key pillar of Islam, as well as a guide business conduct for Calvinistic faith (67), Judaism (68), Christian (66). Religious orientations have a strong explanatory power in relation to variations in work values (69). For the Javanese, religious values of religion have blended into our daily lives, but their spiritual lives are often not pure Islamic values but contain acculturation with cultural values of traditional farmers and even the values of Hindu who had controlled Java island for centuries. Acculturation processes in such a way gradually make Islam the religion and the teachings of Javanese as a cultural entity together and form a different culture from the culture of origin The case due to the "fluidity", the flexing of the old values (70). Consequently, it is still rational when (43) divides the three variants of Javanese religion: Santri, Abangan, and Priyayi. The multiple ethnicities and diverse cultural country, the family provides resources in the face of adversity and challenges. The strong Indonesian family orientation is an expression of collectivism (5). Family structures have a traditional hierarchical structure that includes respect for the positions of status, power, and age. Hierarchy of family plays out in organizing business where bosses are often called the bapak or the $i b u$, meaning father or mother. Javanese integrates a business visionary with a deep spiritual foundation of local community for collective achievement orientation. Education and planting the value directly by the parent can provide the cultural awareness, knowledge, and skills of entrepreneurship. The "art" of entrepreneurial practices are learned through the efforts of trying to directly engage in the business than the formal educational environment (71).

\section{Conclusion}

This interpretive research is a qualitative study based on a small sample of 3 business creative family companies. Life experience entrepreneurship of the second generation is presented in a narrative form and used as a basis for the findings. These findings are not meant to generalize, but more of an offering for empirical insights to understand the theoretical framework of Javanese culture and in order to better understand the phenomenon of Javanese culture values instilled and taught by parents of children related to entrepreneurial behavior. The second-generation experience in running a family business and understanding the cultural values of Java show that transformation process is still adopting the cultural values of the original Java. The results are discussed with the implementation of the principle that uncovers business values when paternalism and harmonious culture are applied as the basic concept of Javanese culture in association with behavior when dealing with parents, employees, competitors and God.

There are four kinds of relationship with one another and to support a finding that. First, the business culture in the second generation found cultural values that rooted from paternalism and harmonious culture characterized by their hierarchy, respect, in keeping harmony; second, the relationship with employees and competitors strengthen their evidence of cultural values to maintain harmony with the main characteristic values: trust, independence, positive thinking, self-reliance, sincere, assertive, and competitors as a source of inspiration and not the opponent; third, Javanese cultural values provide the main function as contextual identity that inherits in the people of Java, the cultural shaper and shaper of values, attitudes, and positive behavior. Fourth, religion has been the main pillars of all relationships behave, where the absolute reliance in Allah (God) has resulted in the values and attitudes with absolute submission (trust) in fate, fortune, luck, and loss in business.

The limitation of the study lies in examining only the representative three second-generation businesses. Additional local and regional researches are still needed to explore other cultures and are a comparison between East Java, Central Java, and Yogyakarta to be better understanding the case. Javanese term depth limitations that can only be perceived and interpreted by the Java makes possible limitations in the explanation of the original meaning. Future research is expected to overcome the existing weaknesses, which may lead to construct a search on a theoretical model of business cultural comparison of Java. The impact of modernization is believed to occur in the third generation, and the reduced use of the Java language that is familiar with their language hierarchy has an impact on business behavior and possibly replaces the national and global culture.

\section{References}

[1] Efferin S, Efferin S, Hartono MS, Hartono MS. Management control and leadership styles in family business: An Indonesian case study. Journal of Accounting \& Organizational Change. 2015;11(1):130-59.

[2] Breton-Miller IL, Miller D, Steier LP. Toward an integrative model of effective FOB succession. Entrepreneurship theory and practice. 2004;28(4):305-28

[3] Freytag A, Thurik R. Entrepreneurship and its determinants in a cross-country setting. Journal of evolutionary Economics. 2007; 17(2):117-31

[4] Morales CE, Holtschlag C. Post materialist values and entrepreneurship: a multilevel approach. International Journal of Entrepreneurial Behavior \& Research. 2013;19(3):266-82.

[5] Hofstede G. Culture's consequences: Comparing values, behaviors, institutions, and organizations across cultures. Thousand Oaks, CA: Sage; 2001.

[6] Todorovic ZW, McNaughton RB. The effect of culture, resources and quality of entrepreneurship on economic development: a conceptual framework. International Journal of Entrepreneurship and Small Business. 2007;4(4):383-96.

[7] J. Wong-MingJi D, H. Kessler E, E. Khilji S, Gopalakrishnan S Cross-cultural comparison of cultural mythologies and leadership patterns. South Asian Journal of Global Business Research. 2014;3(1):79-101.

[8] Geertz C. The interpretation of cultures: Basic books; 1973.

[9] Koentjaraningrat. Javanese culture: Issued under the auspices of the Southeast Asian Studies Program, Institute of Southeast Asian Studies [by] Oxford University Press; 1985.

[10] Beatty A. Varieties of Javanese religion: An anthropological account: Cambridge University Press; 1999.

[11] Maharsiwara S. Moslem in the Javanese Culture Pluralism and the Palace Art Performance. Humaniora. 2006;18(3):226-35.

[12] Efferin S, Hopper T. Management control, culture and ethnicity in a Chinese Indonesian company. Accounting, Organizations and Society. 2007;32(3):223-62.

[13] Magnis-Suseno F. Etika Jawa: sebuah analisa filsafi tentang kebijaksanaan hidup Jawa: Gramedia; 1984.

[14] Rademakers MF. Market organization in Indonesia: Javanese and Chinese family business in the Jamu industry. Organization Studies. 1998;19(6):1005-27.

[15] Hofstede G. Culture's consequences: International differences in work-related values: sage; 1984.

[16] Schwartz SH. An overview of the Schwartz theory of basic values. Online readings in Psychology and Culture. 2012;2(1):11.

[17] Stephan U, Uhlaner LM. Performance-based vs socially supportive culture: A cross-national study of descriptive norms and entrepreneurship. Journal of International Business Studies. 2010;41(8):1347-64. 
[18] Dana L-P. Entrepreneurship in a remote sub-Arctic community. Entrepreneurship Theory and Practice. 1995;20(1):57-72.

[19] De Kok JM, Uhlaner LM, Thurik AR. Professional HRM Practices in Family Owned-Managed Enterprises. Journal of Small Business Management. 2006;44(3):441-60.

[20] Mueller SL, Thomas AS. Culture and entrepreneurial potential: A nine country study of locus of control and innovativeness. Journal of business venturing. 2001;16(1):51-75.

[21] Valliere D. Culture, values and entrepreneurial motivation in Bhutan. Journal of Enterprising Communities: People and Places in the Global Economy. 2014;8(2):126-46.

[22] Zahra SA, Hayton JC, Salvato C. Entrepreneurship in family vs. Non-Family firms: A Resource-Based analysis of the effect of organizational culture. Entrepreneurship theory and Practice. 2004;28(4):363-81.

[23] Bekenstein J, Coley A, Dyer C, Tupper T. Second Canadian Conference on General Relativity and Relativistic Astrophysics. Springer; 1988.

[24] Denison D, Lief C, Ward JL. Culture in family-owned enterprises: recognizing and leveraging unique strengths. Family Business Review. 2004;17(1):61-70.

[25] Dyer WG. Examining the "family effect" on firm performance. Family business review. 2006;19(4):253-73.

[26] Yukl G, Mahsud R. Why flexible and adaptive leadership is essential. Consulting Psychology Journal: Practice and Research. 2010;62(2):81.

[27] Schein EH. Organizational culture and leadership: John Wiley \& Sons; 2010.

[28] Jogulu UD. Culturally-linked leadership styles. Leadership \& Organization Development Journal. 2010;31(8):705-19.

[29] Meek VL. Organizational culture: Origins and weaknesses. Organization studies. 1988;9(4):453-73.

[30] Kessler E, Wong-MingJi D, editors. Window on the world: cultural perspectives of leadership past-present-future. Showcase symposium presented at the Academy of Management Annual Meeting, Chicago, IL; 2009.

[31] Morrison EE, Stevenson AJ, Wang Y-F, Meredith DM. Differences in the intracellular localization and fate of herpes simplex virus tegument proteins early in the infection of Vero cells. Journal of general virology. 1998;79(10):2517-28

[32] Kirzner IM. Perception, opportunity, and profit: University; 1979.

[33] Gilder H, Chhabildas L. Temperature-Dependent Activation Volumes in Zinc. Physical Review Letters. 1971;26(17):1027.

[34] Hofstede G. Management scientists are human. Management science. 1994;40(1):4-13.

[35] Steiner AL, Parker CW, Kipnis DM. Radioimmunoassay for cyclic nucleotides I. Preparation of antibodies and iodinated cyclic nucleotides. Journal of Biological Chemistry. 1972;247(4):1106-13.

[36] Beeka BH, Rimmington M. Entrepreneurship as a career option for African youths. Journal of Developmental Entrepreneurship. 2011;16(01):145-64

[37] Zhang Y, Yang J. New venture creation: evidence from an investigation into Chinese entrepreneurship. Journal of Small Business and Enterprise Development. 2006;13(2):161-73.

[38] Laforet S. Innovation characteristics of young and old familyowned businesses. Journal of Small Business and Enterprise Development. 2013;20(1):204-24.

[39] Pitoyo D. TUNA SATAK BATHI SANAK (KEARIFAN JAWA DALAM ETIKA BISNIS). Jurnal Filsafat.18(2):131-55.

[40] Setiyadi DP, Hum M. Pemahaman kembali local wisdom etnik jawa dalam tembang macapat dan pemanfaatannya sebagai media pendidikan budi pekerti bangsa. MAGISTRA. 2012;24(79):71.

[41] Magnis-Suseno F. Javanese ethics and world-view: The Javanese idea of the good life. 1997

[42] Macpherson I, Brooker R, Ainsworth P. Case study in the contemporary world of research: using notions of purpose, place, process and product to develop some principles for practice. International Journal of Social Research Methodology. 2000;3(1):49-61.

[43] Geertz C. The religion of Java: University of Chicago Press; 1976.
[44] Braun V, Clarke V. Using thematic analysis in psychology. Qualitative research in psychology. 2006;3(2):77-101.

[45] Riessman CK. Narrative methods for the human sciences: Sage; 2008.

[46] Scott JC. The moral economy of the peasant: Rebellion and subsistence in Southeast Asia: Yale University Press; 1977.

[47] Wibowo A, Becker C, Marconi G, Durr J, Price J, Hagmann J, et al. Hyperosmotic stress memory in Arabidopsis is mediated by distinct epigenetically labile sites in the genome and is restricted in the male germline by DNA glycosylase activity. Elife. 2016;5:e13546.

[48] Dana L-P. Entrepreneurship and religion: Edward Elgar Publishing; 2010.

[49] Witham L. Marketplace of the Gods: How economics explains religion: Oxford University Press; 2010

[50] Magnis-Suseno F. Langsir Keprabon: New Order leadership, Javanese culture, and the prospects for democracy in Indonesia. Post-Soeharto Indonesia: renewal or chaos. 1999:214-28.

[51] Collins OF, Moore DG. The enterprising man: Michigan State Univ Pr; 1964.

[52] McClelland DC. Achieving society: Simon and Schuster; 1967.

[53] Sharma P, Chrisman JJ, Chua JH. Strategic management of the family business: Past research and future challenges. Family business review. 1997;10(1):1-35.

[54] Hall A, Melin L, Nordqvist M. Entrepreneurship as radical change in the family business: Exploring the role of cultural patterns. Family Business Review. 2001;14(3):193-208.

[55] Fukuyama F. I. The Primacy of Culture. Journal of Democracy. 1995;6(1):7-14.

[56] Hormozi AM. Becoming an entrepreneur: How to start a small business. International Journal of Management. 2004;21(3):278.

[57] Audia PG, Rider CI. A garage and an idea: what more does an entrepreneur need? California Management Review. 2005;48(1):628.

[58] Ward J, Aronoff C. Trust gives you the advantage. Nation's Business. 1991;79(8):42-5.

[59] Moscetello L. The Pitcairns want you. Family Business Magazine. 1990;19(2):135-45.

[60] Mattessich P, Hill R. Family enterprise and societal development: A theoretical assessment. Journal of Comparative Family Studies. 1976:147-58.

[61] Sapir S, Pratikto H, Wasiti W, Hermawan A. Model Pembelajaran Kewirausahaan Berbasis Kearifan Lokal Untuk Penguatan Ekonomi. Jurnal Pendidikan dan Pembelajaran (JPP). 2015;21(1):79-91.

[62] Ram M, Holliday R. Relative merits: Family culture and kinship in small firms. Sociology. 1993;27(4):629-48.

[63] Syam N. Agama pelacur: dramaturgi transendental: Penerbit \& distribusi, LKiS Yogyakarta bekerja sama dengan IAIN Sunan Ampel Press, Surabaya; 2010.

[64] Wright L, Tellei VC. Women in management in Indonesia. International Studies of Management \& Organization. 1993;23(4):19-45.

[65] Miller DW, Ewest T. Rethinking the impact of religion on business values: Understanding its reemergence and measuring its manifestations. Dimensions of Teaching Business Ethics in Asia: Springer; 2013. p. 29-38.

[66] Nwankwo S, Gbadamosi A. Faith and entrepreneurship among the British African-Caribbean: Intersections between religious and entrepreneurial values. Journal of Small Business and Enterprise Development. 2013;20(3):618-33.

[67] Neusner J. From politics to piety: Ktav Publishing House; 1979

[68] Kotkin J. Tribes: How race, religion, and identity determine success in the new global economy: Random House Incorporated; 1993.

[69] Parboteeah DV, Valacich JS, Wells JD. The influence of website characteristics on a consumer's urge to buy impulsively. Information Systems Research. 2009;20(1):60-78.

[70] Tago MZ. Agama dan Integrasi Sosial dalam Pemikiran Clifford Geertz. KALAM. 2017;7(1):79-94.

[71] Jack SL, Anderson AR. Entrepreneurship education within the enterprise culture: producing reflective practitioners. International Journal of Entrepreneurial Behavior \& Research. 1999;5(3):110-25. 